\title{
Preliminary Study of the Vertical Axis Wind Turbine (VAWT) Prototype at Urban Area
}

\author{
Fauzun Atabiq ${ }^{1, *}$, Didi Istardi' ${ }^{1}$, Ridwan', Arif Febriansyah Juwito ${ }^{1}$, Irwanto Zarma Putra ${ }^{1}$, \\ Muhammad Agil Wildan', Muhammad Ridlo Alfianto', Rahman Hakim² \\ ${ }^{1}$ Batam Polytechnics \\ Electrical Engineering study Program \\ Parkway Street, Batam Centre, Batam 29461, Indonesia \\ *E-mail: atabiq@polibatam.ac.id \\ ${ }^{2}$ Batam Polytechnics \\ Mechanical Engineering Study Program \\ Parkway Street, Batam Centre, Batam 29461, Indonesia
}

\begin{abstract}
This research complements the shortcomings of PLTB, namely by adding a Monitoring System to the Wind Power Plant at Batam State Polytechnic. By addition of sensors, installations, and a control panel containing instruments for monitoring wind conditions, Savonius turbine rpm, and pico-generator output electrical characteristics. The method used is conventional, starting from mechanical design, program development, and installation to testing. This study's preliminary results indicate that wind at the PLTB Polibatam location is not continuous. It does not occur, even though the maximum wind speed can reach $8.9 \mathrm{~m} / \mathrm{s}$. The implementation of the savonius-type wind turbine in this study can generate electricity around $87.83 \mathrm{~kW} /$ week or about $0.61 \mathrm{~kW} /$ hour.
\end{abstract}

Kata kunci: Harvesting wind energy, Savonius type, Vertical axis wind turbine, Experimental study

\section{Introduction}

Wind energy is environmentally friendly, abundant, and renewable (energy that has no end). Wind energy in Indonesia has great potential, but the development of wind energy in Indonesia is classified as low, ranging from $3 \mathrm{~m} / \mathrm{s}$ to $5 \mathrm{~m} / \mathrm{s}$, making it challenging to produce electrical energy on a large scale [1], [2]. However, the potential for wind in Indonesia makes it possible to develop a small-scale power generation system due to the available wind potential almost all year round [3].

Based on data from the Ministry of Energy and Mineral Resources in 2006, Indonesia has a wind energy potential of $9.29 \mathrm{GW}$, and $0.0005 \mathrm{GW}$ installed. The government has currently issued a roadmap for the utilization of renewable energy, which targets the installed capacity by 2025 to reach $17 \%$ [4].

Decentralization of wind power production is favourable because it will reduce generator size, allowing application in urban areas with problematic wind flows due to many buildings and obstacles. In small-scale wind power plants, vertical axis turbines are very suitable compared to horizontal axis turbines because there is no need to align the turbine with the wind direction [5]. Several types of vertical axis turbines can be used in wind power plants [6]. The savonius wind turbine is a vertical axis wind turbine that can operate well at low wind speeds [7], [8].

In any wind power project, the reliability of the wind turbine system is considered as a critical component. This is necessary for the development and maintenance of wind power systems [9]. The evaluation of critical parameters in the system will improve the detection of complex components and reduce time wasted in maintaining wind power plants [10].

The purpose of this study is to analysis the performance of implementation of the savonius-type wind turbine in urban area, specially at Batam islands.

\section{Materials and Method}

The Savonius turbine is one of the simplest turbines. Aerodynamically, they are drag-type devices, consisting of two or three vertical blades - half a cylinder. A two-bladed savonius wind turbine will 
look like an "S" shape in cross-section [11]. The savonius turbine design in this study uses three blades, as shown in Figure 1.

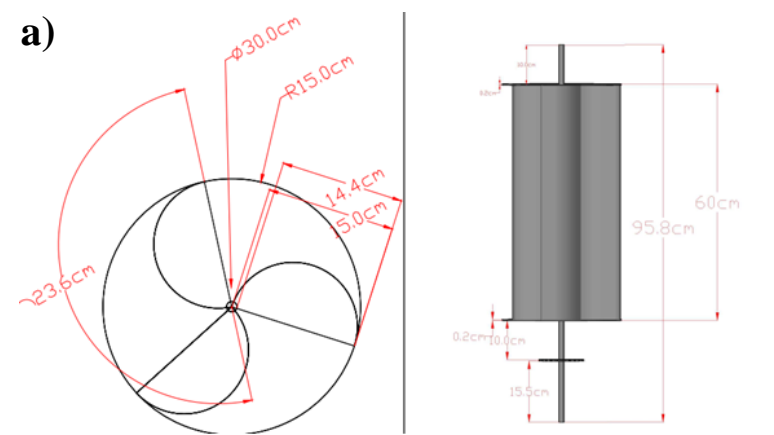

b)

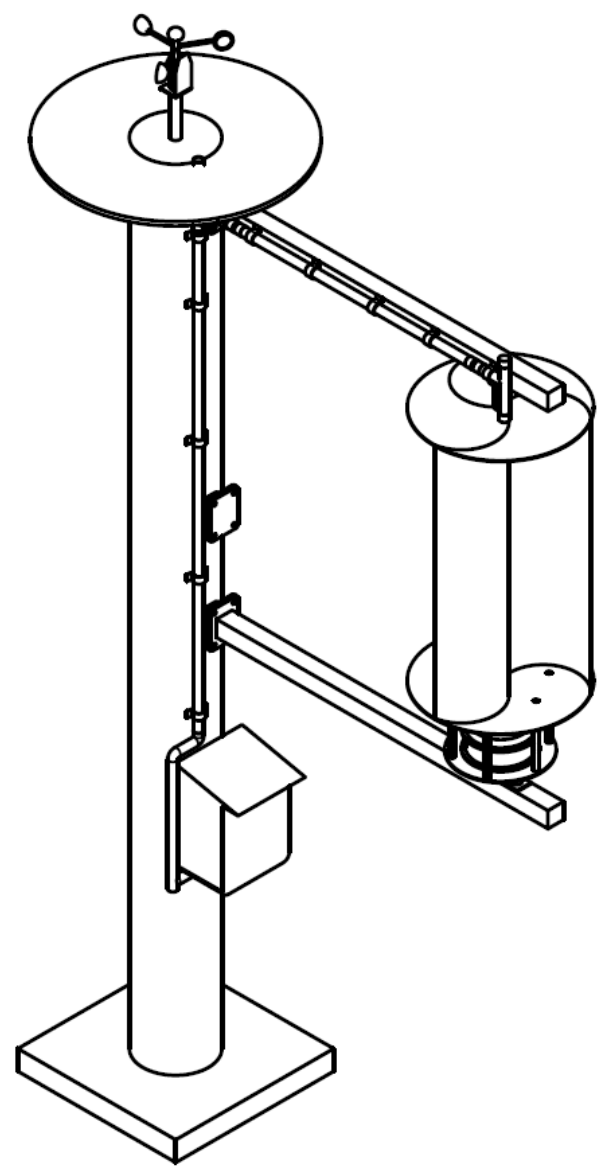

Figure 1. Preliminary Design of Vertical-Axis Wind Turbine, a) Cross-Section of Savonius-Type, b) 3D Model Data

In any measured form, power is derived from the force times the distance divided by the period. Wind power is measured in various units depending on the application the researcher uses for wind power. The power extracted from the wind is not affected by changes in air density except for areas with very extreme climates and at high altitudes. Wind power is also directly proportional to the area swept. Doubling the sweep factor also doubles the output power.

In addition, the estimated potential power generated by wind energy is also greatly influenced by wind speed. Wind speed in the formula is a cubic function, so doubling the speed will increase the power eightfold. The basic equation for wind power is an equation used to estimate the power extracted from the mass of a moving fluid [11]. Equation 1 is an estimate of the energy potential that can be generated by wind energy.

$$
\mathrm{P}=1 / 2 . \rho \cdot \mathrm{A} \cdot \mathrm{V}^{3} \cdot \mathrm{E}
$$

Equation 1 shows $\mathbf{P}$ is power (Watt), $\boldsymbol{\rho}$ is the density of air $\left(\mathrm{m}^{3} / \mathrm{kg}\right), \mathbf{A}$ is swept are of the turbine $\left(\mathrm{m}^{2}\right), \mathbf{V}$ is wind velocity $(\mathrm{m} / \mathrm{s})$, and $\mathbf{E}$ are the efficiency rotor and generator.

\section{Results and Discussion}

Figure 2a shows that the Batam State Polytechnic environment's wind speed, especially at the PLTB location, is not continuous. Sometimes it is high, medium, sometimes there is no wind. The monitoring results show that the maximum wind speed at the PLTB location in the Batam State Polytechnic is $9.8 \mathrm{~m}$ / s. During the monitoring, the wind speed at the PLTB location in Figure 2, the wind in the location is unable to move the generator.

The graph in Figure $2 \mathrm{~b}$ shows that during monitoring after $10 / 12 / 2020$, the turbine is not rotating at all, or the turbine speed $=0 \mathrm{rpm}$. Even though it showed a high value at the beginning, the speed of the savonius turbine reached above $1000 \mathrm{rpm}$, but this was a test carried out by turning the turbine manually. This test ensures the sensor, LCD panel, and data acquisition on the SD memory card are working.

Based on the data in Figure $2 b$, it can also be ascertained that after $12 / 10 / 2020$, the savonius wind turbine at this PLTB has never rotated. Although when looking at the wind speed data in Figure 2a, the wind at the PLTB location is sometimes present and is classified as high, reaching $9.8 \mathrm{~m} / \mathrm{s}$. The zero data could be caused by the power transmission method used, namely, the direct coupling transmission system for the external rotor generator is not suitable. 

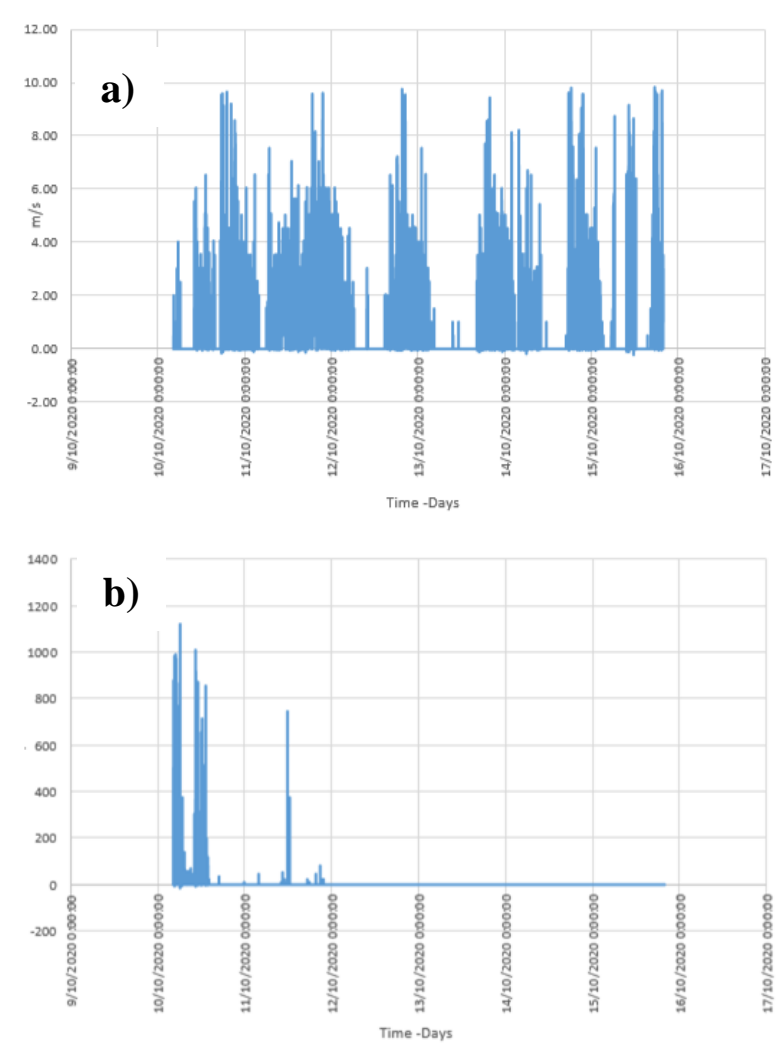

Figure 2. Experimental Data, a) Real-Time Wind Velocity, b) Wind Turbine Performance

Figure 3 shows that during monitoring, the terminal voltage value of the PLTB Generator shows a particular voltage value. Besides, on the following days, the terminal voltage was still there and showed a value below 1 Volt. The low output voltage could be due to the coding program that has not done zero tuning.

In the early days of monitoring, on 10/20/2020, the generator terminal voltage reached 12 volts, but for the following days, the generator terminal voltage showed a minimum value, less than 1 Volt. The terminal voltage value of the PLTB generator related to the turbine speed data in Figure 2 is correct.

The generator terminal value was reached and reached 12 volts. At that time, the system sensor reading was tested, and the PLTB savonius turbine in this study was rotated manually. The Savonius turbine is coupled directly to the external generator rotor than the generator rotates when the Savonius turbine rotates.

The implementation of PLTB in this study, as shown in Figure 4, uses a savonius wind turbine with three blades with a blade diameter of $\mathrm{d}=0.3 \mathrm{~m}$ and a length of $h=0.6 \mathrm{~m}$ so that the swept area is $\mathrm{A}=0.18 \mathrm{~m} 2$. The approach method to the density value of air at the Batam State Polytechnic PLTB is 1,184 kg / m3. The total efficiency of Er x Eg x Et is 0.45. Applying Eq 1, estimating the potential electrical energy generated from the savonius wind turbine in this study is shown in Figure 4.

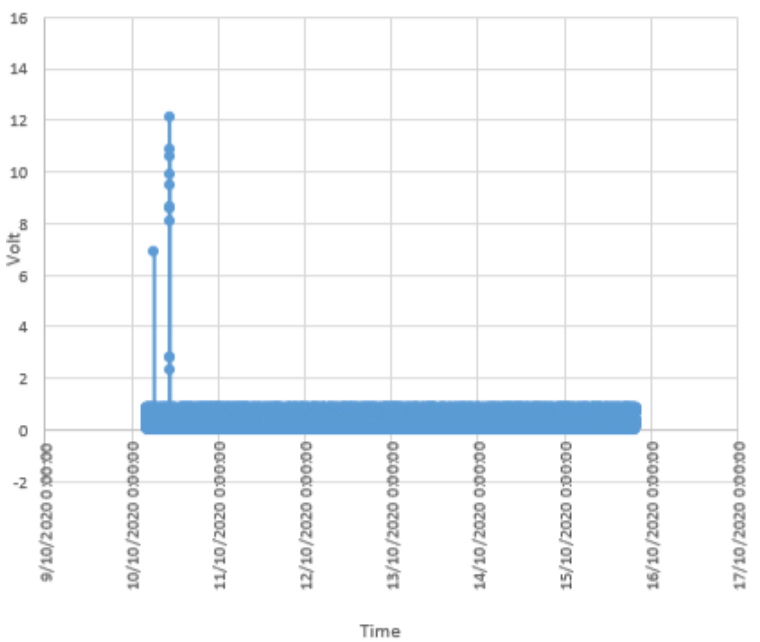

Figure 3. Generator Terminal Voltage

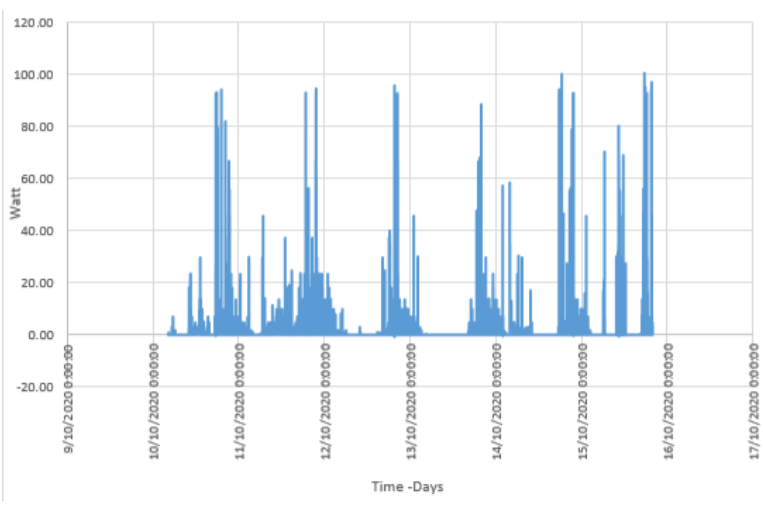

Figure 4. Energy Estimated Data

As in Equation 1 and the implementation of savonius turbine in PLTB in the Batam State Polytechnic environment (Figure 1), if the PLTB can work well, the estimated amount of energy can be generated $87.83 \mathrm{~kW} /$ week or an average of about $0.61 \mathrm{~kW} / \mathrm{h}$.

\section{Conclusions}

The monitoring system built for PLTB at Batam State Polytechnic has worked well. From the observation of PLTB in Polibatam, the observation shows that the presence of wind at the PLTB location is not continuous. It disappears, even though the maximum wind speeds up to 8.9 m.s-1. Implementation the savonius type of wind turbine in this study can generate electricity around $87.83 \mathrm{~kW} /$ week, or about $0.61 \mathrm{~kW} /$ hour.

The application of power transmission using a belt or direct coupling for the savonius turbine to the external rotor type generator cannot be used. Another method is needed so that the initial torque required to rotate the generator is relatively small. The wind turbine torque produced can overcome the mechanical losses 
in the PLTB built so that the generator can rotate and produce a voltage at the generator terminal.

\section{Acknowledgment}

This work is supported by the research grant of the Ministry of Education and Culture (MOEC) at Politeknik Negeri Batam, Riau Islands, Indonesia.

\section{References}

[1] G. Surya et al., "Karakteristik Suhu Permukaan Laut dan Kecepatan Angin di Perairan Batam Hubungannya dengan Indian Ocean Dipole ( IOD )," Natl. Semin. Mar. Fish., vol. 6, no. 1, pp. 1-6, 2017.

[2] M. Z. Lubis, W. Anurogo, H. Kausarian, G. Surya, and T. Choanji, "Sea Surface Temperature and Wind Velocity in Batam Waters Its Relation to Indian Ocean Dipole (IOD)," J. Geosci. Eng. Environ. Technol., vol. 2, no. 4, p. 255, 2017.

[3] F. Atabiq, B. Budiana, A. F. J, I. Syahri, and I. Saputra, "Modification of Two Poles Single Phase," J. Integr., vol. 11, no. 1, pp. 68-73, 2019.

[4] M. Effendy, "Penggunaan Teknologi MPPT (Maximum Power Point Tracker) Pada Sistem Pembangkit Listrik Tenaga Angin (PLTB),” Tek. Elektro Univ. Muhammadiyah Malang, vol. 4, p. 5, 2006.

[5] F. Castellani, D. Astolfi, M. Peppoloni, F. Natili, D. Buttà, and A. Hirschl, "Experimental vibration analysis of a small scale vertical wind energy system for residential use," Machines, vol. 7, no. 2, pp. 1-19, 2019.

[6] D. Istardi and A. Wirabowo, "Rancang Bangun Square Wave Full-Bridge Inverter," J. Manutech, vol. 9, no. 1, pp. 18-23, 2017.

[7] M. Zemamou, M. Aggour, and A. Toumi, "Review of savonius wind turbine design and performance," in 4th International Conference on Power and Energy Systems Engineering, 2017, vol. 141, pp. 383-388.

[8] J. H. Purba and F. B. Harlan, "Analisa Aplikasi Turbin Kobold Blade Kembar Sebagai Pembangkit Listrik Tenaga Arus Laut," in 7th Applied Business and Engineering Conference,
2020, no. November 2019.

[9] S. Costinas, I. Diaconescu, and I. Fagarasanu, "Wind power plant condition monitoring," in Proceedings of the 3rd WSEAS International Conference on Energy Planning, Energy Saving, Environmental Education, EPESE '09, Renewable Energy Sources, RES '09, Waste Management, WWAI '09, 2009, no. May 2014, pp. 71-76.

[10] M. L. Wymore, J. E. Van Dam, H. Ceylan, and D. Qiao, "A survey of health monitoring systems for wind turbines," Renew. Sustain. Energy Rev., vol. 52, no. 1069283, pp. 976-990, 2015.

[11] M. Hadi Ali, "Experimental Comparison Study for Savonius Wind Turbine of Two \&amp; Three Blades At Low Wind Speed," Int. J. Mod. Eng. Res. www.ijmer.com, vol. 3, no. 5, pp. 2978-2986, 2013.

9 | Jurnal Integrasi | Vol.13 No.1, April 2021, 6-9 | e-ISSN: 2548-9828 